\title{
Investigation of effects of fluorosis on some minerals and hormones in sheep*
}

\author{
Bahat COMBA ${ }^{1}$, Ali ÇINAR ${ }^{2}$ \\ ${ }^{1}$ Yuzuncu Yil University, Faculty of Veterinary Medicine, Department of Physiology, Van, Turkey; ${ }^{2}$ Ataturk University, Faculty of \\ Veterinary Medicine, Department of Physiology, Erzurum, Turkey.
}

\begin{abstract}
Summary: This study was carried out to determine the effects of fluorosis on plasma fluor (F), serum calcium (Ca), phosphorus $(\mathrm{P})$, magnesium $(\mathrm{Mg})$, calcitonin $(\mathrm{CT})$, intact parathyroid hormone (iPTH) and vitamin $\mathrm{D}_{3}\left(\mathrm{~V}_{\text {it }} \mathrm{D}_{3}\right)$ in sheep. A total of 75 Morkaraman sheep, 50 with chronic fluorosis (Fluorotic group) from Tendürek Mountain region (altitude about $2000 \mathrm{~m}$ ) and 25 without any fluorosis (Control group) from Van (altitude 1700m) were used, aged 3-4 years. Data collected 50 sheeps with chronic fluorosis in the in East Anatolia, Van-Agri, Turkey, were compared with data from 25 without any fluorosis sheeps from the Van region. Plasma F levels were measured with spesific fluride electrode, serum $\mathrm{Ca}, \mathrm{P}$ and $\mathrm{Mg}$ levels were photometrically determined; serum CT and iPTH levels were determined using chemiluminescent immunometric assay, serum $V_{i t} \mathrm{D}_{3}$ level were analysed with HPLC method. Serum $\mathrm{P}$ and Vit $\mathrm{D}_{3}$ levels were lower in fluorotic group than in control group $(\mathrm{p}<0.001)$, while serum CT ( $\left.<<0.01\right)$ and $\mathrm{iPTH}(\mathrm{p}<0.001)$ levels were higher. The differences for $\mathrm{Ca}$ and $\mathrm{Mg}$ values were found statistically nonsignificant. The results obtained were after a long term exposure of sheep to high amounts of fluorine and supports occurrence of osteomalatic conditions. In conclusion, clean water should be given to animal and people who live in this region because of irreversible pathological situation occurs after fluorosis develops. Otherwise, $\mathrm{Ca}, \mathrm{P}, \mathrm{Mg}$ and $\mathrm{Vit} \mathrm{D}_{3}$ supplementations has to be given at proper doses to prevent negative effects of fluoride on teeth and bones.
\end{abstract}

Keywords: Calcium, fluorosis, parathyroid hormone, sheep, Vitamin D.

\section{Florozisin koyunlarda bazı mineraller ve hormonlar üzerine etkilerinin araştırılması}

Özet: $\mathrm{Bu}$ çalışmada; florozisin koyunlarda plazma flor $(\mathrm{F})$, serum kalsiyum $(\mathrm{Ca})$, fosfor $(\mathrm{P})$, magnezyum $(\mathrm{Mg})$, kalsitonin $(\mathrm{CT})$, intakt paratiroid hormon $(\mathrm{iPTH})$ ve vitamin $\mathrm{D}_{3}$ (Vit $\mathrm{D}_{3}$ ) üzerine etkileri araştırıldı. Araştırmada 3-4 yaşlarında 50 tanesi Tendürek Dağı (yaklaşık 2000 m) bölgesinde kronik florozisli (Florozisli grup) ve 25 tanesi Van bölgesinden (1700 m) florozis belirtisi göstermeyen (Kontrol grubu) toplamda 75 Morkaraman Koyunu kullanıldı. Türkiye' nin Doğu Anadolu bölgesindeki VanAğrı şehirlerinden kronik florozisli 50 koyundan toplanan veriler, Van bölgesinde florozis belirtisi göstermeyen 25 koyunla karşılaştırıldı. Plazma F seviyeleri spesifik flor elektrodu ile ölçüldü, serum Ca, P ve Mg seviyeleri fotometrik yolla, serum CT ve iPTH seviyeleri immünometrik kemilüminesans assay yöntemi ile belirlendi, serum Vit $\mathrm{D}_{3}$ seviyesi HPLC metodu ile analiz edildi. Florozisli gruptaki serum $\mathrm{P}$ ve Vit $\mathrm{D}_{3}$ seviyeleri düşük $(\mathrm{p}<0.001)$, serum $\mathrm{CT}(\mathrm{p}<0.01)$ and $\mathrm{iPTH}(\mathrm{p}<0.001)$ düzeyleri kontrol grubundan yüksekti. Ca ve $\mathrm{Mg}$ değerleri istatistiksel olarak önemsizdi. Elde edilen bulgular, uzun süreli ve yüksek miktarda flora maruz kalma sonucunda koyunlarda osteomalatik durumun oluşabileceğini desteklemektedir. Sonuç olarak, florozis şekillendikten sonra dişlerde ve iskelet sisteminde dönüşü olmayan patolojik bir durum söz konusu olduğundan, bu bölgede yaşayanlara temiz su kaynakları verilmeli. Aksi durumda florun dişler ve kemikler üzerindeki olumsuz etkisini önlemek için uygun dozlarda Ca, $\mathrm{P}, \mathrm{Mg}$ ve Vit $\mathrm{D}_{3}$ ilavesi yapılmalıdır.

Anahtar sözcükler: Florozis, kalsiyum, koyun, paratiroid hormon, Vitamin D.

\section{Introduction}

Fluorosis is known for clinical symptoms such as horizontal, yellow-brown lines, mottling and wear on teeth, osteosclerosis and osteoporosis in bones, deformation and arthritis in the spine, femur and knees, and articular dysfunction of the shoulder. Ruminants such as sheep, goats and cattle are more sensitive to fluorosis than other animals. In contrast, pig and horses are partially resistant to the disease, while birds are immune (1).

Fluorosis occurs when animals consume water and feed that grow in soil that has high fluoride content due to water sources that are rich in fluoride. It is also sometimes observed in areas where water and feed are contaminated due to pollution from industrial processes. Fluorosis not only causes health problems, it also creates

\footnotetext{
This study was prepared from $\mathrm{PhD}$ thesis of first author and were presented as a poster at the 39 . Congress of the National Physiology.
} 
economic problems due to productivity losses in animal husbandry (25).

Recently, studies have been carried out on the effects of fluorosis on the ECG levels of sheep (7) and dogs (16) and in the T3 and T4 levels of cows (5) and goats (2). There are some studies about the effects of fluorosis on certain antioxidants (6) and vitamins (32). However, a review of the literature did not reveal a sufficient number of studies investigating the effects of fluorosis on the levels of plasma fluoride $(\mathrm{F})$, serum calcium $(\mathrm{Ca})$, phosphorus $(\mathrm{P})$, magnesium $(\mathrm{Mg})$, calcitonin (CT), intact parathyroid hormone (iPTH) and vitamin $\mathrm{D}\left(\right.$ Vit $\left.\mathrm{D}_{3}\right)$.

The purpose of this study was to make a contribution to the literature on this subject by researching the levels of $\mathrm{F}, \mathrm{Ca}, \mathrm{P}, \mathrm{Mg}, \mathrm{CT}$, iPTH and Vit $\mathrm{D}_{3}$ in sheep with fluorosis that are raised and fed on the foothills of Mount Tendürek, which is located in the provinces of Van and Agri and has volcanic rock that is very influential on the character of the soil in comparasion of sheep without chronic fluorosis.

\section{Materials and Methods}

Animal groups: A total of 75 animals were used. Fluorotic group included 50 Morkaraman Sheep aged 3-4 years that had clinical symptoms of fluorosis from Tendürek Mountain region (altitude about $2000 \mathrm{~m}$ ) in East Anatolia, Van-Agri region, Turkey. This region is known with water and food sources with high levels of fluoride so that these animals took fluoride with water and food continuously $(6,24,32)$. The Control group consisted of 25 without any fluorosis sheep that were of the same breed and age as the Fluorotic group. Control group had no symptoms of fluorosis and were raised in the Farm of Yuzuncu Yil University, Van- Centrum, Turkey (altitude $1700 \mathrm{~m}$ ). Because previous studies for the fluorine level of drinking water in Van was reported as normal levels (24).

The fluorotic group was checked for clinical symptoms such as fluorosis of the teeth, palpable bone exostoses, mandibular defects, anomalies of the ribs, metacarpal and metatarsal defects, hoof deformities, lameness and weakness. In the control group there were no sings of chronic fluorosis.

Analysis: Plasma fluoride test was carried out with a specific F electrode $(2,8,24,28)$ serum $\mathrm{Ca}, \mathrm{P}$ and $\mathrm{Mg}$ analysis was performed with a photometric method (23), serum CT and iPTH analyses were carried out using a chemiluminescent immunometric assay and Vit $\mathrm{D}_{3}$ levels were measured with HPLC method (26).

Statistical analysis: SAS statistical program was used to perform the statistical analysis. Data were stored and analyzed by SAS (Version, 1998). A t-Test for independent groups was used to test the significance of the differences between the averages of the two groups (control and fluorotic) with regard to each parameter being studied.

\section{Results}

This study evaluated the effect of fluorosis on $F$, $\mathrm{Ca}, \mathrm{P}, \mathrm{Mg}, \mathrm{CT}$, iPTH and Vit $\mathrm{D}_{3}$ in sheep and the interactions of these mineral substances and hormones, which normally affect the bone mineral density of the skeletal system, in animals with fluorosis. The values and statistical results obtained in the study have been given in Table 1.

Serum $\mathrm{P}$ and Vit $\mathrm{D}_{3}$ levels were lower in fluorotic group than in control group, while serum CT and $\mathrm{PTH}$ levels were higher. The statistical significance between $\mathrm{P}$, vitamin $\mathrm{D}_{3}$ and iPTH levels between the groups was $\mathrm{p}<0.001$ and the difference in $\mathrm{CT}$ values was $\mathrm{p}<0.01$, while the differences for $\mathrm{Ca}$ and $\mathrm{Mg}$ values were found statistically nonsignificant.

\section{Discussion and Conclusion}

The amount of fluoride in the blood is a significant laboratory finding used to diagnose fluorosis. The normal plasma fluoride levels of farm animals are less than 0.2 ppm. In farm animals poisoned with fluoride, this value has been found to be $0.6 \mathrm{ppm}$ (4). In this study, the plasma fluoride levels of sheep in the control group were

Table 1. Levels of F, Ca, P, Mg, CT, iPTH, Vit $\mathrm{D}_{3}$ in Control and Fluorotic groups.

Tablo 1. Kontrol ve Florozisli gruplarda F, Ca, P, Mg, CT, iPTH, Vit $\mathrm{D}_{3}$ seviyeleri.

\begin{tabular}{lccccc}
\hline Parameters & $\mathrm{n}$ & $\begin{array}{c}\text { Control Group } \\
\bar{X} \pm \mathrm{SE}\end{array}$ & $\mathrm{n}$ & $\begin{array}{c}\text { Fluorotic Group } \\
\bar{X} \pm \mathrm{SE}\end{array}$ & $\mathrm{p}$ \\
\hline Fluoride $(\mathrm{ppm})$ & & $0.13 \pm 0.02$ & 50 & $0.38 \pm 0.04$ & $<0.001$ \\
Calcium $(\mathrm{mg} / \mathrm{dl})$ & 25 & $9.15 \pm 0.17$ & 50 & $9.34 \pm 0.37$ & - \\
Phosphorus $(\mathrm{mg} / \mathrm{dl})$ & 25 & $6.23 \pm 0.32$ & 50 & $2.28 \pm 0.21$ & $<0.001$ \\
Magnesium $(\mathrm{mg} / \mathrm{dl})$ & 25 & $2.44 \pm 0.18$ & 50 & $2.51 \pm 0.34$ & - \\
Calcitonin $(\mathrm{pg} / \mathrm{ml})$ & 25 & $165.13 \pm 12.53$ & 50 & $192.28 \pm 15.35$ & $<0.01$ \\
Intact parathyroid hormone $(\mathrm{pg} / \mathrm{ml})$ & 25 & $7.41 \pm 0.21$ & 50 & $16.20 \pm 1.39$ & $<0.001$ \\
Vitamin $\mathrm{D}_{3}(\mu \mathrm{g} / \mathrm{ml})$ & 25 & $0.033 \pm 0.005$ & 50 & $0.023 \pm 0.004$ & $<0.001$ \\
\hline
\end{tabular}


$0.13 \pm 0.02 \mathrm{ppm}$, while the plasma fluoride levels in the fluorotic group were found to be $0.38 \pm 0.04$. This value is close to the levels found in this region for sheep with fluorosis $(2,24)$.

Because the skeletal system is the primary location for storing fluoride, it is the place where the beneficial and detrimental effects of fluoride are most often seem. Calcium hydroxyapatite is the primary basis for bone mineralization. When the concentration of fluoride in the plasma increases, it replaces the $\mathrm{OH}$-ion in the apatite crystal, forming calcium fluorapatite (22). In fluorosis, because $\mathrm{Ca}$ mobilization from calcium fluorapatite crystals is reduced, new bone formation and the occurrence of osteoclastic resorption is the secondary result of the increased effects of parathormone (9). Calcium ions combine with fluoride ions to form $\mathrm{CaF}_{2}$, thus preventing the absorption of fluoride. In this study, the $\mathrm{P}$ values between the groups was found to be statistically significant $(\mathrm{p}<0.001)$. No statistically significant differences were found for $\mathrm{Ca}$ and $\mathrm{Mg}$ values between both groups. These values conform to those reported in previous studies $(17,20,21,32)$.

The fact that serum $P$ levels were found to be lower in sheep with fluorosis than in those in the control group may be related to the excessive secretion of parathormone. In this case, there is increased excretion of $\mathrm{P}$ in urine. It is known that in fluorosis, the concentration of fluoride in the blood increases and accumulates in the bones in the form of fluorapatite. Thus, in sheep with fluorosis, Ca levels are initially low, stimulating the excretion of parathormone, which causes more $\mathrm{Ca}$ to be absorbed through the intestines and immobilized in the bones. This situation can increase serum Ca levels. Fluoride can cause hypocalcemia both by reducing the absorption of calcium through the gastrointestinal system and binding to calcium; if calcium intake is also insufficient, it can cause a secondary increase in parathormone.

The concentration of $\mathrm{Ca}$ in the blood plays a major role in PTH synthesis and secretion. There is an inverse sigmoidal relationship between PTH and Ca. However, secretion of PTH cannot be completely suppressed, even with very high Ca levels (18). There is also an inverse relationship between $\mathrm{Mg}$ levels and secretion of PTH, but PTH secretion is reduced in cases of chronic hypomagnesemia (12).

By binding to the receptors in the cell membrane, PTH exhibits its primary effects on kidneys and bones by means of cAMP. PTH's most important function is to prevent hypocalcemia by increasing calcium resorption from the kidneys and increasing calcium resorption in the bones (12). The increase in serum PTH levels due to fluorosis supports the findings in previous studies (11, 13, 27).
CT rapidly reduces plasma calcium and phosphate levels, thus exhibiting the opposite effect of PTH. An increase in the level of calcium ions in the plasma causes reduced PTH secretion, decreased absorption of calcium ions in the intestines and kidneys, and increased elimination from the body. In addition, the fixation of $\mathrm{CaHPCO}_{4}$ in the bone tissue increases. As a result, more calcium is removed from the blood, thus maintaining a normal level. However, in hypercalcemia where calcium level in the blood increases excessively, this process is not fully effective. In such a situation, CT gets involved by rapidly reducing the levels of excessive calcium in the blood to normal levels. When hypercalcemia reaches dangerous levels, the secretion of CT also increases. In this way, the level of plasma calcium is reduced and the body is protected from hypercalcemia (12).

CT has no effect on the absorption of calcium in the gastrointestinal system. CT does increase renal clearance by reducing tubular reabsorption of calcium and phosphorus in the kidneys. CT limits the conversion of 25-OH-cholecalciferol $(25(\mathrm{OH}) \mathrm{D})$ to the $\mathrm{D}$ hormone. Reduced levels of D hormone in the blood in turn prevent the absorption of calcium and phosphorus in kidney tubules, thus preventing it from passing into the blood. Consequently, CT indirectly reduces the level of calcium and phosphorus in the blood, but increases its elimination in the urine (21). In this study, the difference in the serum CT values was statistically significant $(\mathrm{p}<0.01)$. Previous studies that point to the increase in serum CT levels in cases of fluorosis also support this study $(14,31)$.

In a study (3), $\mathrm{NaF}$ was given to 10 sheep for 10 months at the dose of $4 \mathrm{ppm}$ in order to develop the experimental fluorosis. At the end of the study, the level of PTH was lower and CT was higher in the fluorotic group than controls. In the presedent study, CT and PTH levels were found high. Although they try to adjust the level of $\mathrm{Ca}$, low level of $\mathrm{P}$ and osteomalatic conditions can be associated with chronic fluorosis.

When plasma the level of $25(\mathrm{OH}) \mathrm{D}$ falls below a critical level or when $\mathrm{Ca}$ absorption through the intestines is insufficient, PTH levels increase (secondary hyperparathyroidism), 1-hydroxylase enzymes become active due to the effect of PTH, and 1,25(OH)2D levels increase (29). This point vitamin $\mathrm{D}$ begins mobilizing $\mathrm{Ca}$ from bones. Because the serum $\mathrm{Ca}$ level is more important for the organism, $\mathrm{Ca}$ is now mobilized from the bones through the combined activity of $1,25(\mathrm{OH}) 2 \mathrm{D}$ and $\mathrm{PTH}$, in an attempt is made to keep the Ca level within a normal range. During this process, bone mineralization is disrupted even further (12).

Production of $1,25 \mathrm{OHD}_{3}$ increases due to the limited supply of Vit $\mathrm{D}_{3}$. As a result, $25 \mathrm{OHD}_{3}$ depots are rapidly depleted and long term intake of excessive 
fluoride can cause secondary vitamin D deficiency. Furthermore, continued long term intake of high amounts of $\mathrm{F}$ can not only affect kidney functions at various levels (1), it can also result in kidney stones (30), frequently urinary tract infections (19) and a reduction in renal function occur (10). It has been reported that the occurrence of secondary hyperparathyroidism can cause excessive bone resorption (12). In this study, the difference in serum $D_{3}$ levels was statistically significant $(\mathrm{p}<0.001)$. This finding supports the literature (15).

In conclusion, when fluorosis endemic, high levels of fluoride occur in the blood due to the high doses of fluoride in drinking water and plants. This fluoride in the blood rapidly combines with calcium to form the compound $\mathrm{CaF}_{2}$. Because of this compound, the level of free $\mathrm{Ca}$ in the blood drops. In order to bring the low level of blood $\mathrm{Ca}$ back to normal, the secretion of PTH increases. In order to lower the increasing level of $\mathrm{Ca}, \mathrm{C}$ cells in the thyroid gland are stimulated and the amount of CT increases. The increased levels of PTH and CT literally compete with each other in an attempt to balance the levels of $\mathrm{Ca}, \mathrm{P}$ and $\mathrm{Mg}$ in plasma. The low level of vitamin $\mathrm{D}_{3}$ makes the body predisposed to meet the need for $\mathrm{Ca}$ from the bones by means of PTH instead of from the intestines. This makes it easier to eliminate phosphorus. As a result, the ratio of $\mathrm{Ca} / \mathrm{P}$ increases, causing weak bones, lameness and easy bone breakage.

Due to the fact that the treatment of fluorosis has not been fully described, we recommend that people living in areas that contain high levels of fluoride drink defluorinated water, that they fortify animal feed with fluoride precipitants such as calcium carbonate, magnesium or aluminum compounds, that they reduce the negative effects of fluorosis by also using vitamin $\mathrm{C}$ and vitamin $\mathrm{E}$ supplements, and that they protect animals from stress. In addition, we recommend that they administer $\mathrm{Ca}, \mathrm{P}, \mathrm{Mg}$ and vitamin $\mathrm{D}$ preparations to animals either via injection or by adding it to their food in suitable doses in order to reduce the activity of PTH and CT.

\section{References}

1. Altıntaş A, Fidancı UR, Sel T, et al. (2000): Serum proteins electrophoresis and kidney function in sheep with natural and industrial fluorosis. Vet J Ankara Univ, 2, 105-114.

2. Arslan S (2008): The relationship between thyroid hormones and fluoride levels in goats, with fluorosis, University of Yuzuncu Yil, Institute of Health Science Department of Internal Diseases, PhD Thesis, Van, Turkey.

3. Başaran B, Kaya N (2004): Deneysel kronik florozis oluşturulmuş tuj ırkı koyunlarda serum paratiroid hormon $(P T H)$ ve kalsitonin $(C T)$ tayini. XVIII. Ulusal Kimya Kongresi, Kars.
4. Blood DC, Radostits OM, Henderson JA (1983): Fluorine Poisoning. Veterinary Medicine, Sixth Edition, London.

5. Çınar A, Selçuk M (2005): Effects of chronic fluorosis on thyroxine, triiodothyronine, and protem-bound iodine in cows. Fluoride, 1, 65-68.

6. Doğan İ (2002): Investigation of antioxidant compounds of fluorotic sheep, Yuzuncu Yil University, Health Science Institute, Department of Biochemistry MSci. Thesis, Van, Turkey.

7. Dönmez N, Çınar A (2003): Effects of chronic fluorosis on electrocardiogram in sheep. Biol Trace Elem Res, 2, 115-122.

8. Duly EB, Luney SR, Trinick TR, et al. (1995): Validation of an ion selective electrode system for the analysis of serum fluoride ion. J Automat Chem, 6, 219-223.

9. Faccini JM, Teoita SPS (1974): Histopathological assessment of endemic skeletal fluorosis. Calcified Tissue Res, 1, 45-47.

10. Greenberg SR (1986): Response of the renal supporting tissues to chronic fluoride exposure as revealed by a special technique. Urol Int, 41, 91-94.

11. Gupta SK, Khan TI, Gupta RC (2001): Compensatory hyperparathyroidsm following high fluoride ingestion biochemical correlation. Indian Pediatr, 38,139-146.

12. Guyton AC (2007): Textbook of Medical Physiology. 11th ed. Philadelphia: W.B. Saunders Company.

13. Huang Z, Li K, Hou G, et al. (2002): Study on the correlation of the biochemical indexes in fluoride workers. Zhonghua Lao Dong Wei Sheng Zhi Ye Bing Za Zhi 3, 192-194

14. Junxiang M, Mingfeng L, Yu'e S, et al. (2009): Serum osteocalcin and calcitonin in adult males with different fluoride exposures. Fluoride, 2, 133-136.

15. Khandare AL, Harikumar R, Sivakumar B (2005): Severe bone deformities in young children from vitamin d deficiency and fluorosis in Bihar-India. Calcif Tissue Int, 76, 412-418.

16. Kılıçalp D, Çınar A, Belge F (2004): Effects of chronic fluorosis on electrocardiogram in dogs. Fluoride, 2, 96100.

17. Kirvar E (1991): Serum levels of calcium, phosphorus, sodium, potassium, urea and uric acid in normal sheep and sheep showing signs of fluorosis in Eastern Anatolia. Ankara University Health Science Institute Department of Biochemistry PhD Thesis, Ankara, Turkey.

18. Kruse K (1995): Endocrine control of calcium and bone metabolism, 712-743. In: Clinical Paediatric Endocrinology, 3th ed, Backwell Science Ltd, Oxford.

19. Lantz O, Jouvin MH, De Vernejoul MC, et al. (1987): Fluoride-induced chronic renal failure. Am J Kidney Dis, 10, 136-139.

20. Maraşlı Ş, Maraşlı N, Yenigün A (1995): The preliminary report on hypocupraemia in sheep enzootic fluorosis. Kafkas Univ Vet Fak Derg, 1-2, 79-81.

21. Mittal RL, Sidhu SS, Khokhar SS (1987): Role of copper in skelatal changes in fluorosis, An experimental study in rabbits. Fluoride, 3, 104-108.

22. Mjor IA (2002): Pulp-dentin biology in restorative dentistry, China. Quintessence Publishing Co, Inc. 
23. Morton S, Roberts DJ (1993): University of Bristol Unicam AAS Methods, Manual Issue, 2 (05/93), England.

24. Oto G (2002): The effect of seasonal changes on fluor levels in water and blood samples taken from sheep living in the region of Muradiye and Caldiran. University of Yuzuncu Y1l Health Sciences Institute, Ms. Sci. Thesis in Pharmacology and Toxicology, Van, Turkey.

25. Patra RC, Dwivedi SK, Bhardwaj B, et al. (2000): Industrial fluorosis in cattle and buffalo around Udaipur, India. Sci Total Environ, 253, 145-150.

26. Reynolds SL, Judd HJ (1984): Rapid procedure for the determination of vitamins a and in fortified skimmed milk powder using high-performance liquid chromatography, Analyst, 109, 489-492.

27. Sharifian A, Momeni Vr, Shahriaran S, et al. (2008): Serum calcium and parathyroid hormone levels in aluminum potroom workers exposed to fluorlde emissions. Fluoride, 4, 314-316.

28. Shi SX, Zhu ZG, Suo R, et al. (2003): Rapid method for the determination of trace fluoride and activation of ionselective. Electrode Analytical Sci, 19, 671-673.

29. Shills ME, Olson JA, Shike M, et al. (1999): Modern Nutrition in Health and Disease, 9th edition, Baltimore, Williams \& Williams.
30. Singh PP, Barjatiya MK, Dhing S, et al. (2001): Evidence suggesting that high intake of fluoride provokes nephrolithiasis in tribal populations. Urol Res, 4, 238244.

31. Tokar VI, Voroshnin VV, Sherbakov SV (1989): Chronic effects of fluorides on the pituitary-thyroid system in industrial workers in Russian. Gig Tr Prof Zabol, 9, 1922.

32. Yaşar S (2003): Investigation of the vitamins and mineral levels in sheep with fluorosis. Yuzuncu Yil University, Health Science Institute, Department of Biochemistry MSci. Thesis, Van, Turkey.

Geliş tarihi: 13.01.2015 / Kabul tarihi: 11.08.2015

Address for correspondence:

Yrd. Doç. Dr. Bahat COMBA,

Yuzuncu Yil University

Faculty of Veterinary Medicine, Department of Phsiology, Postal code: 65080, Zeve Campus, Van, Turkey.

e-mail: bahatcomba@hotmail.com.tr 